\title{
Destruction of Ion-Exchange Resin in Waste from the HFIR, T1, and T2 Tanks Using Fenton's Reagent
}

October 2002

Prepared by

P. A. Taylor 


\title{
DOCUMENT AVAILABILITY
}

Reports produced after January 1, 1996, are generally available free via the U.S. Department of Energy (DOE) Information Bridge.

\section{Web site http://www.osti.gov/bridge}

Reports produced before January 1, 1996, may be purchased by members of the public from the following source.

\author{
National Technical Information Service \\ 5285 Port Royal Road \\ Springfield, VA 22161 \\ Telephone 703-605-6000 (1-800-553-6847) \\ TDD 703-487-4639 \\ Fax 703-605-6900 \\ E-mail omfp@mtos/fedwpr;d/gpv \\ Web site http://www.ntis.gov/support/ordemowabout.htm
}

Reports are available to DOE employees, DOE contractors, Energy Technology Data Exchange (ETDE) representatives, and International Nuclear Information System (INIS) representatives from the following source.

Office of Scientific and Technical Information

P.O. Box 62

Oak Ridge, TN 37831

Telephone 865-576-8401

Fax 865-576-5728

E-mail reports@adonis.osti.gov

Web site http://www.osti.gov/contact.html

\begin{abstract}
This report was prepared as an account of work sponsored by an agency of the United States Government. Neither the United States government nor any agency thereof, nor any of their employees, makes any warranty, express or implied, or assumes any legal liability or responsibility for the accuracy, completeness, or usefulness of any information, apparatus, product, or process disclosed, or represents that its use would not infringe privately owned rights. Reference herein to any specific commercial product, process, or service by trade name, trademark, manufacturer, or otherwise, does not necessarily constitute or imply its endorsement, recommendation, or favoring by the United States Government or any agency thereof. The views and opinions of authors expressed herein do not necessarily state or reflect those of the United States Government or any agency thereof.
\end{abstract}


Nuclear Science and Technology Division

\section{DESTRUCTION OF ION-EXCHANGE RESIN IN WASTE FROM THE HFIR, T1, AND T2 TANKS USING FENTON'S REAGENT}

P. A. Taylor

Date Published: October 2002

Prepared by

OAK RIDGE NATIONAL LABORATORY

P.O. Box 2008

Oak Ridge, Tennessee 37831-6285

managed by

UT-BATTELLE, LLC

for the

U.S. DEPARTMENT OF ENERGY

under contract DE-AC05-00OR22725 


\section{CONTENTS}

LIST OF FIGURES




\section{LIST OF FIGURES}

Figure

Page

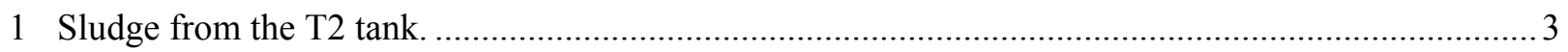

2 Laboratory-scale equipment using a closed bottle................................................................ 4

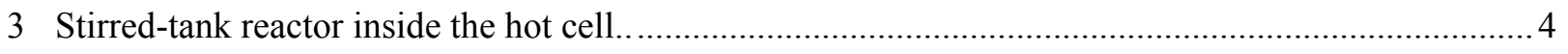

4 Concentration of soluble TOC in simulant slurries during treatment.......................................... 7

5 Effect of temperature on peroxide reaction rate in $\mathrm{T} 1$ and $\mathrm{T} 2$ simulant slurries. ............................. 8

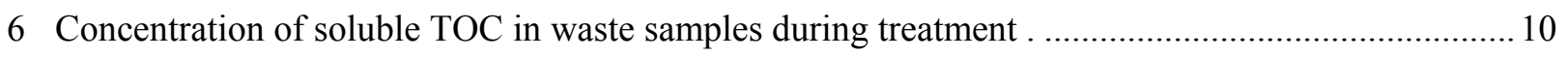

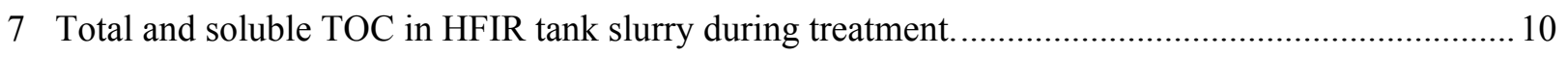

8 Carbon dioxide concentration in off-gas from treatment of HFIR tank sample............................. 11

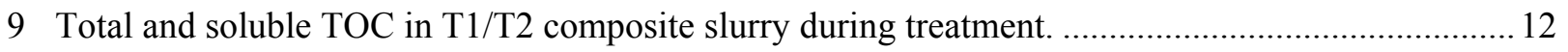

10 Carbon dioxide and oxygen concentrations in off-gas during treatment

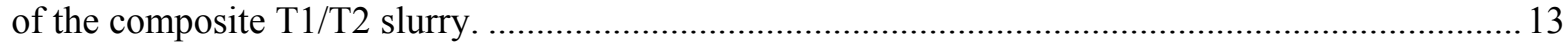

11 Carbon monoxide concentration and off-gas generation rate during treatment of the composite $\mathrm{T} 1 / \mathrm{T} 2$ slurry.

\section{LIST OF TABLES}

\section{Table}

Page

1 Analytical data for sludge from the HFIR, T1, and T2 tanks .................................................. 3

2 Analytical data for new samples from the HFIR, T1, and T2 tanks ............................................ 6 


\section{ACKNOWLEDGMENTS}

This work was sponsored by the U.S. Department of Energy's Environmental Management (EM-50)

Program Tanks Focus Area, under contract DE-AC05-00OR22725 with UT-Battelle, LLC. Conduct of the experimental effort was supported by Tom Hylton, Doug Lee, Barry Spencer, Frank Riley, and Bob Cummins all of the Nuclear Science and Technology Division. Their efforts are highly appreciated. Chemical analyses of the liquid and slurry samples were performed by the Radioactive Materials Analysis Laboratory. Analysis of volatile organics in the gas samples was performed by Ralph Ilgner and Roger Jenkins of the Chemical Sciences Division. The samples from the HFIR, T1, and T2 tanks were collected by personnel from Duratek Federal Services. 


\begin{abstract}
The use of Fenton's reagent (hydrogen peroxide and a ferrous iron catalyst) has been tested as a method for destroying ion-exchange resin in radioactive waste from three underground storage tanks at the Oak Ridge National Laboratory. The resin in these wastes must be destroyed before they can be transferred to the Melton Valley Storage Tanks (MVSTs) prior to solidification and disposal at the Waste Isolation Pilot Plant. The reaction with ion-exchange resin requires a dilute acidic solution ( $\mathrm{pH}=3$ to 5) and moderate temperatures $\left(\mathrm{T}=60\right.$ to $\left.100^{\circ} \mathrm{C}\right)$. Laboratory-scale tests of the process have been successfully completed using both simulants and actual waste samples. The ion-exchange resin is oxidized to carbon dioxide and inorganic salts. The reaction rate is quite slow for temperatures below $70^{\circ} \mathrm{C}$ but increases almost linearly as the temperature of the slurry increases from 70 to $90^{\circ} \mathrm{C}$.

Pilot-scale tests have demonstrated the process using larger samples of actual waste slurries. A sample from the High Flux Isotope Reactor (HFIR) tank, containing $500 \mathrm{~mL}$ of settled solids (resin and inorganic sludge) in a total volume of $1800 \mathrm{~mL}$, was successfully treated to meet MVST waste acceptance requirements in $9 \mathrm{~h}$ of processing time, using $1650 \mathrm{~mL}$ of $50 \mathrm{wt} \%$ hydrogen peroxide. A composite sample from the T1 and T2 tanks, which contained $1000 \mathrm{~mL}$ of settled solids in a total volume of $2000 \mathrm{~mL}$ required $8 \mathrm{~h}$ of treatment, using $1540 \mathrm{~mL}$ of $50 \mathrm{wt} \%$ peroxide, to meet waste acceptance requirements. Hydrogen peroxide reaction rates were 0.71 to $0.74 \mathrm{~g} \mathrm{H}_{2} \mathrm{O}_{2} / \mathrm{L} / \mathrm{min}$, with very low $(<2000 \mathrm{mg} / \mathrm{L})$ concentrations of peroxide in the slurry.

The reaction produces mostly carbon dioxide gas during the early part of the treatment, when organic carbon concentrations in the slurry are high, and then produces increasing amounts of oxygen as the organic carbon concentration drops. Small amounts $(<3 \mathrm{vol} \%)$ of carbon monoxide are also generated. The off-gas from the pilot-scale tests, which was $81 \mathrm{vol} \%$ nitrogen purge gas and $19 \mathrm{vol} \%$ gas generated by the reaction, also showed trace quantities of numerous volatile organics. Maximum concentrations measured were $48 \mathrm{ppm}$ diethylbenzene, $40 \mathrm{ppm}$ acetone, and $21 \mathrm{ppm}$ benzene, with a maximum total volatile organic concentration of $122 \mathrm{ppm}$.
\end{abstract}




\section{INTRODUCTION}

The Oak Ridge National Laboratory (ORNL) has a mixture of transuranic sludge and organic ionexchange resin stored in two inactive underground storage tanks (the T1 and T2 tanks). The waste must be retrieved and treated for disposal to meet the site Federal Facilities Compliance Agreement; however, it does not meet waste acceptance criteria for any existing treatment/storage facility. Other transuranic slurries from ORNL have been collected in the Melton Valley Storage Tanks (MVSTs) and will be solidified by a private-sector contractor for eventual disposal at the Waste Isolation Pilot Plant; however, the organic ion-exchange resins from the T1 and T2 tanks are not acceptable in the MVSTs. Small-scale tests, using various combinations of acids, chelators, and oxidizing/reducing agents, have shown that it is not feasible to leach enough of the plutonium from the resin to yield a nontransuranic solid low-level waste. The only practicable option is the destruction of the resins, leaving an inorganic transuranic slurry that would meet the waste acceptance criteria for transfer to the MVSTs. The supernate currently stored in the MVSTs contains an average concentration of $770 \mathrm{mg} / \mathrm{L}^{1}$ of soluble total organic carbon (TOC), and the sludge contains an average concentration of 10,200 ppm total TOC. ${ }^{2}$ These values represent the TOC levels that the treated waste should not exceed.

Laboratory-scale tests using both simulants and small samples of actual waste have shown that the ion-exchange resin can be destroyed using Fenton's reagent (hydrogen peroxide and a ferrous iron catalyst), which oxidizes the resin to carbon dioxide and ammonium sulfate. A third inactive tank, the High Flux Isotope Reactor (HFIR) tank, also contains radioactive ion-exchange resin, but this waste is not transuranic. Although the HFIR tank waste could be stabilized and disposed of as low-level waste, it would be less expensive to use the same equipment and process that will be used to treat the wastes in tanks $\mathrm{T} 1$ and $\mathrm{T} 2$.

AEA Technology (Mooresville, N.C.) has been chosen to build and operate a full-scale system to treat the waste in the HFIR, T1, and T2 tanks. The treatment goal is to reduce the TOC concentration in the waste slurries to below that of the waste currently stored in the MVSTs. The system will include a pulse-jet mixer to mobilize the waste in the tanks, a reaction vessel, an offgas scrubber, a chemical feed system, and support equipment. AEA Technology has previously built and tested a system in England that uses Fenton's Reagent to treat ion-exchange resin from submarines and other organic wastes.

\section{MATERIALS AND METHODS}

The Fenton's reagent process involves the reaction of hydrogen peroxide $\left(\mathrm{H}_{2} \mathrm{O}_{2}\right)$ with a ferrous iron catalyst to form hydroxyl free radicals (Reaction 1). Other transition metal ions, such as $\mathrm{Cu}$, $\mathrm{Mn}$, and $\mathrm{Ni}$, can also be used to generate hydroxyl free radicals from hydrogen peroxide. With an oxidation potential of $2.8 \mathrm{~V}$, the hydroxyl free radical is a very powerful oxidant and will react with a wide range of organic molecules. ${ }^{3-8}$ The sludge in the HFIR, T1, and T2 tanks contains sufficient iron for the catalytic reaction. Consequently, addition of iron is not required, and no additional sludge or salts are created during the treatment. The reaction is exothermic ( $\sim 500 \mathrm{~kJ} / \mathrm{mol}$ of peroxide consumed) and can be very rapid. The reaction with ion-exchange resin requires a dilute acidic solution $(\mathrm{pH}=3$ to 5$)$ and moderate temperatures $\left(\mathrm{T}=60\right.$ to $100^{\circ} \mathrm{C}$ ). The ion-exchange resin is initially solubilized to linear polystyrene sulfonates and amines (Reaction 2), which are then further oxidized through a series of intermediates to carbon dioxide 
and ammonium sulfate (Reaction 3). The ferrous ion catalyst is regenerated by reaction with additional peroxide (Reaction 4) or by reaction with organic radicals formed during oxidation of the resins. The hydroxyl radicals can also react with additional peroxide, which is a wasteful side reaction (Reaction 5). Maintaining a low concentration of peroxide in the reaction slurry and a slightly acidic $\mathrm{pH}$ keeps the concentrations of reactants $\left(\mathrm{H}_{2} \mathrm{O}_{2}\right.$ and $\left.\mathrm{OH}^{-}\right)$low and reduces the amount of peroxide wasted.

Hydroxyl free radical formation

$\mathrm{H}_{2} \mathrm{O}_{2}+\mathrm{Fe}^{2+} \rightarrow \mathrm{Fe}^{3+}+\mathrm{OH}^{-}+\mathrm{OH} \bullet$ (radical)

$\underline{\text { Reaction with ion-exchange resin }}$

$\mathrm{OH} \bullet+$ IX Resin $\rightarrow$ linear polystyrene sulfonates and amines

$\mathrm{OH} \bullet+$ linear polystyrene sulfonates and amines $\rightarrow\left(\mathrm{NH}_{4}\right)_{2} \mathrm{SO}_{4}+\mathrm{CO}_{2}+\mathrm{H}_{2} \mathrm{O}$

Iron catalyst regeneration

$\mathrm{H}_{2} \mathrm{O}_{2}+2 \mathrm{Fe}^{3+} \rightarrow 2 \mathrm{Fe}^{2+}+2 \mathrm{H}^{+}+\mathrm{O}_{2}$

Peroxide decomposition

$\mathrm{OH} \bullet+\mathrm{H}_{2} \mathrm{O}_{2}+\mathrm{OH}^{\mathrm{G}} \rightarrow 2 \mathrm{H}_{2} \mathrm{O}+\mathrm{O}_{2}$

The linear polystyrene sulfonates, produced by the breakdown of the ion-exchange resin, are a type of detergent and can cause foaming in the reaction mixture. Foam generation and possible temperature excursions from the exothermic reaction can be limited by controlling the rate of peroxide addition and avoiding a buildup of peroxide in the reaction mixture. Organic acids are initially formed as the linear sulfonates and amines are degraded, causing the $\mathrm{pH}$ of the reaction mixture to drop. Sodium hydroxide is added to maintain the $\mathrm{pH}$ in the range of 3 to 5 . During the last part of the reaction, while the remaining organic acids are being completely oxidized to carbon dioxide, the $\mathrm{pH}$ can rise; therefore, nitric acid may need to be added to maintain the $\mathrm{pH}$. The reaction rate slows as the $\mathrm{pH}$ drops below 3 , and peroxide decomposition increases if the $\mathrm{pH}$ is above 5 .

Core samples of the sludge from the HFIR, T1, and T2 tanks were taken in 1999 and analyzed at the ORNL Radioactive Materials Analysis Laboratory (RMAL). A photograph of the sludge from the T2 tank is shown in Fig. 1, and the waste from the other tanks is similar in appearance. The samples were separated into supernate and sludge portions. The supernate contained very low concentrations of radionuclides and metals. The concentrations of the main contaminants in the sludge from these samples are shown in Table 1. Because they are adsorbed on the ionexchange resin, concentrations of normally soluble cations, such as $\mathrm{Na}, \mathrm{K}$, and $\mathrm{Cs}$, are high in the sludge, but low in the supernate. The sludges also contain small amounts $(10-80 \mathrm{ppm})$ of $\mathrm{Cu}$, $\mathrm{Mn}$, and $\mathrm{Ni}$, which can also act as catalysts for producing hydroxyl radicals. About $100 \mathrm{~mL}$ each of the T1 and T2 samples was archived at RMAL and later retrieved and used for the two laboratory-scale treatment tests using actual waste samples.

Most of the resin destruction experiments used nonradioactive simulant slurries of the waste in the T1 and T2 tanks, which were prepared using reagent-grade chemicals. Equal amounts of strong-acid cation resin (Amberjet ${ }^{\circledR}$ 1500, Rohm and Haas Co., Philadelphia, Pa.) and strongbase anion resin (Amberjet $\left.{ }^{\circledR} 4400\right)$ were added to the simulants. 


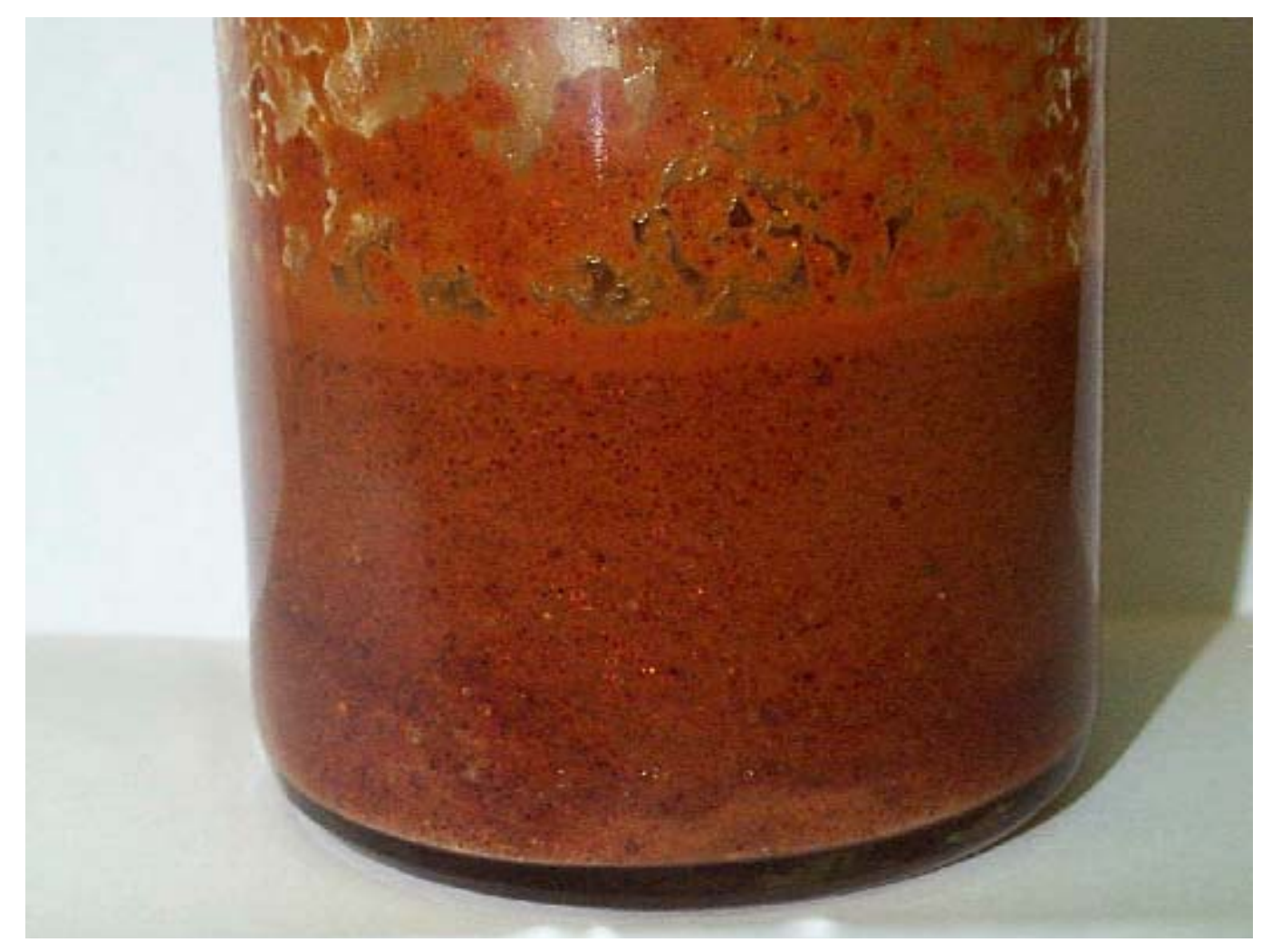

Fig. 1. Sludge from the T2 tank.

Table 1. Analytical data for sludge from the HFIR, T-1, and T-2 tanks

\begin{tabular}{lrrr}
\hline Contaminant & HFIR tank & T1 tank & T2 tank \\
\hline $\mathrm{Al}(\mathrm{mg} / \mathrm{kg})$ & 515 & 436 & 511 \\
$\mathrm{Ca}(\mathrm{mg} / \mathrm{kg})$ & 11,100 & 3,990 & 2,760 \\
$\mathrm{Fe}(\mathrm{mg} / \mathrm{kg})$ & 3,230 & 2,750 & 3,370 \\
$\mathrm{~K}(\mathrm{mg} / \mathrm{kg})$ & 150 & 6,220 & 7,450 \\
$\mathrm{Mg}(\mathrm{mg} / \mathrm{kg})$ & 2,300 & 760 & 583 \\
$\mathrm{Na}(\mathrm{mg} / \mathrm{kg})$ & 4,350 & 10,500 & 6,930 \\
$\mathrm{Total} \mathrm{TOC}(\mathrm{mg} / \mathrm{kg})$ & 71,800 & 83,800 & 80,300 \\
$\mathrm{U}(\mathrm{mg} / \mathrm{kg})$ & $<10$ & 125 & 2,740 \\
${ }^{60} \mathrm{Co}(\mathrm{Bq} / \mathrm{g})$ & 67,000 & 58,000 & 48,000 \\
${ }^{137} \mathrm{Cs}(\mathrm{Bq} / \mathrm{g})$ & 7,400 & 97,000 & 330,000 \\
${ }^{90} \mathrm{Sr}(\mathrm{Bq} / \mathrm{g})$ & 43 & 180,000 & $2,000,000$ \\
${ }^{238-240} \mathrm{Pu}(\mathrm{Bq} / \mathrm{g})$ & 166 & 20,700 & 86,300 \\
${ }^{244} \mathrm{Cm}(\mathrm{Bq} / \mathrm{g})$ & 700 & 169,300 & 803,700 \\
\hline
\end{tabular}


For the laboratory-scale treatment tests, a hot plate was used to maintain the temperature of the test slurries between 60 and $90 \mathrm{EC}$ during the reaction. A dual-head peristaltic pump was used to add $50 \mathrm{wt} \% \mathrm{H}_{2} \mathrm{O}_{2}$ solution and either $1 \mathrm{~N} \mathrm{NaOH}$ or $1 N \mathrm{HNO}_{3}$ to the slurry. The acid/base pump head was disengaged periodically, as needed, to maintain the $\mathrm{pH}$ between 3 and 5. A redox potential probe was used to monitor the peroxide concentration in the slurry, and samples were taken periodically to measure the peroxide concentration using Reflectoquant ${ }^{\circledR}$ test strips (EM Science, Gibbstown, N.J.). Samples of supernate were analyzed for soluble TOC. Although most of the simulant tests and both of the tests using real waste were conducted in an open beaker, a few of the simulant tests were conducted in a closed bottle with a vent line for collecting gas samples (see Fig. 2). The gas was analyzed for oxygen $\left(\mathrm{O}_{2}\right)$, nitric oxide (NO), and carbon monoxide (CO), using a Model 400 emissions monitoring system (ENERAC, Inc., Westbury, N.Y.), and some samples were analyzed for $\mathrm{CO}_{2}$ using a gas chromatograph. The laboratoryscale tests using real waste were conducted inside a glove box for contamination control.

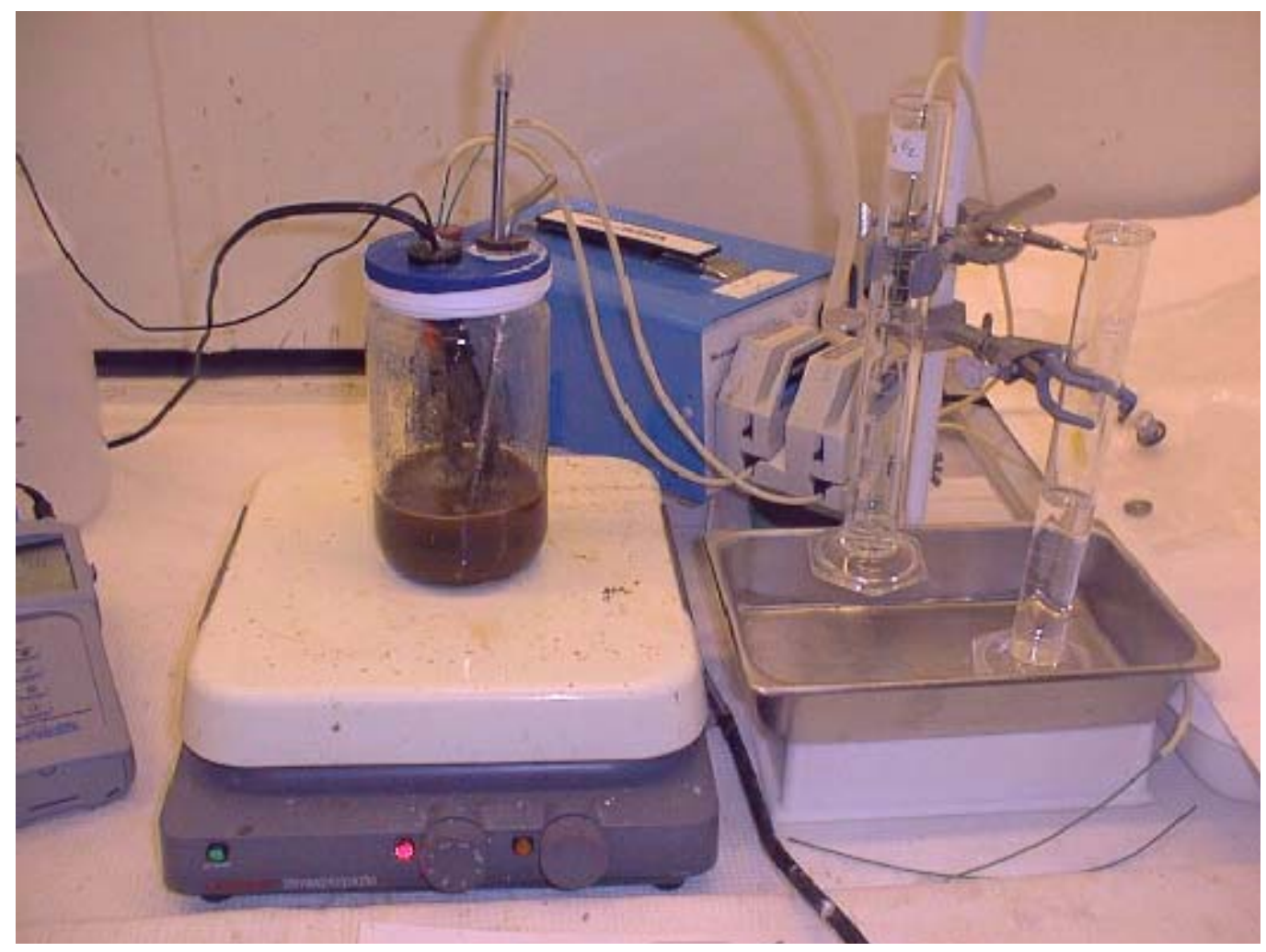

Fig. 2. Laboratory-scale equipment using a closed bottle.

Pilot-scale tests were conducted in a stirred-tank stainless steel reactor located inside a hot cell (see Fig. 3). The level probe (LIC-2) extends down into the reactor. The clear PVC pipe that slopes down to the left is the condenser. The top part of the recirculation pump can be seen at the bottom center of the photograph. The reactor has a working volume of $10 \mathrm{~L}$, with dimensions of $20 \mathrm{~cm}$ ID by $30 \mathrm{~cm}$ tall. The reactor has a heating/cooling coil, which also functions as a draft tube for the stirrer. Heated ethylene glycol-water was pumped through the coil from a heater/chiller located outside the hot cell. Instrumentation includes a level probe and thermocouple inside the reactor and $\mathrm{pH}$ and redox potential probes in an external recirculation line. A condenser and condensate collection bottle remove water vapor from the off-gas. 
A second heater/chiller supplies glycol water at 5EC to the condenser. Nitrogen gas was added to the reactor at $1500 \mathrm{~cm}^{3} / \mathrm{min}$, and $1000 \mathrm{~cm}^{3} / \mathrm{min}$ of off-gas was pulled from the reactor using a mass-flow control valve and a venturi. Because the stirrer and level probe in the reactor were not completely sealed, the venturi was needed to pull the off-gas from the reactor. The off-gas was routed through a fourier transform infrared (FTIR) analyzer (TEMET Instruments, Finland) to measure the carbon dioxide concentration. Samples of off-gas were periodically analyzed using the ENERAC monitor. Peristaltic pumps, located outside the hot cell, were used to supply $50 \%$ hydrogen peroxide and either $2 \mathrm{~N} \mathrm{NaOH}$ or $1 \mathrm{NHNO}_{3}$ to the reactor. A computer control and data acquisition system monitored the liquid level and temperature inside the reactor, the nitrogen purge and off-gas rates, and the results from the FTIR analyzer. The pumping rates, and $\mathrm{pH}$ and redox readings were monitored manually.

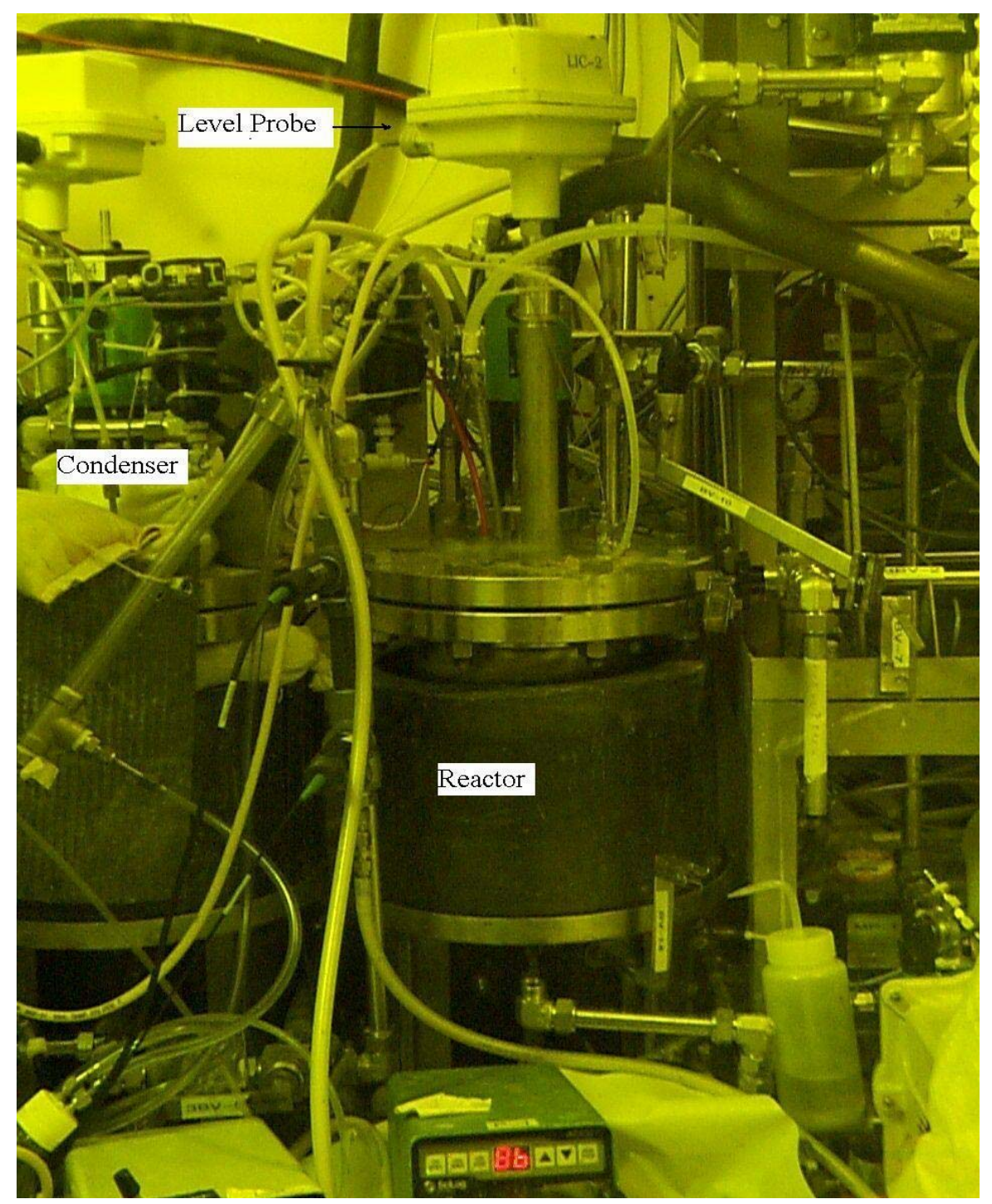

Fig. 3. Stirred-tank reactor inside the hot cell. 
New samples from each of the tanks were collected for the pilot-scale tests. The sample from the HFIR Tank contained $500 \mathrm{~mL}$ of settled solids in a total volume of $1800 \mathrm{~mL}$. Samples from the $\mathrm{T} 1$ and T2 tanks were mixed to form a composite sample for treatment. The T1 sample contained $360 \mathrm{~mL}$ of sludge, and the T2 sample contained $720 \mathrm{~mL}$. After some of the slurry was removed for analysis, the composite sample that was treated in the pilot-scale test contained $1000 \mathrm{~mL}$ of settled solids in a total volume of $2000 \mathrm{~mL}$. Analytical results for both samples are shown in Table 2. Soluble TOC is measured by filtering a portion of the sample and injecting the clear liquid into the TOC-5000 analyzer (Shimadzu Scientific Instrument Co., Columbia, MD). The total TOC is measured by acidifying a portion of the slurry, drying at $250 \mathrm{EC}$, and then burning the dried solids in the solids module of the TOC-5000 instrument. The samples contained low concentrations of ${ }^{14} \mathrm{C}$, which could be present as $\mathrm{CO}_{2}$ in the off-gas from the treatment process.

AEA Technology's previous experience has suggested that copper ions are beneficial in degrading the organic amines produced from solubilization of anion-exchange resins. Because AEA Technology plans to add additional copper to the tank slurries during full-scale treatment, $2.0 \mathrm{~g}$ of $\mathrm{Cu}\left(\mathrm{NO}_{3}\right)_{2}$ were added to each of the slurries used in the pilot-scale tests.

Table 2. Analytical data for new samples from the HFIR, T1, and T2 tanks

\begin{tabular}{lrr}
\hline Analysis & HFIR tank & T1/T2 composite \\
\hline Density $(\mathrm{g} / \mathrm{mL})$ & 1.055 & 1.049 \\
Total TOC $(\mathrm{mg} / \mathrm{kg})$ & 40,700 & 46,900 \\
Soluble TOC $(\mathrm{mg} / \mathrm{L})$ & 333 & 339 \\
${ }^{60} \mathrm{Co}(\mathrm{Bq} / \mathrm{g})$ & 10,000 & 14,000 \\
${ }^{137} \mathrm{Cs}(\mathrm{Bq} / \mathrm{g})$ & $\mathrm{ND}^{*}$ & 87,000 \\
${ }^{14} \mathrm{C}(\mathrm{Bq} / \mathrm{g})$ & 62 & 16 \\
${ }^{238-240} \mathrm{Pu}(\mathrm{Bq} / \mathrm{g})$ & $\mathrm{ND}$ & 33,000 \\
${ }^{244} \mathrm{Cm}(\mathrm{Bq} / \mathrm{g})$ & 440 & 107,000 \\
\hline
\end{tabular}

${ }^{*} \mathrm{ND}=$ Not Detected

\section{RESULTS}

\subsection{Laboratory-Scale Tests}

Treating $100 \mathrm{~mL}$ of simulant slurry, which contained $20 \mathrm{~g}$ of ion-exchange resin, typically required about $10 \mathrm{~h}$ of treatment, $180 \mathrm{~mL}$ of $50 \% \mathrm{H}_{2} \mathrm{O}_{2}$, plus $50 \mathrm{~mL}$ of $1 \mathrm{~N} \mathrm{NaOH}$, and then $15 \mathrm{~mL}$ of $1 \mathrm{~N} \mathrm{HNO}_{3}$ to control the $\mathrm{pH}$. The concentration of $\mathrm{H}_{2} \mathrm{O}_{2}$ in the slurry was normally below $4000 \mathrm{mg} / \mathrm{L}$, and the temperature was usually kept at 70 to $80 \mathrm{EC}$. The concentration of soluble TOC in the slurry was initially zero, then increased as the ion-exchange resin was solubilized, and finally decreased as the soluble organics were oxidized to carbon dioxide gas. Figure 4 shows the TOC results for three of the simulant tests. The concentration of soluble TOC in the slurry depends on the balance between solubilization of the ion-exchange resin and conversion of the soluble organics to carbon dioxide. 
Thin layers of foam were present periodically while the simulant slurries were being treated. For the tests conducted in the closed bottle, the total gas generation was about $25 \mathrm{~L}$ for treating $100 \mathrm{~mL}$ of simulant. The gas composition was 60 to $80 \mathrm{vol} \%$ carbon dioxide during the first half of the test, fell to about $20 \mathrm{vol} \% \mathrm{CO}_{2}$ after all of the resin was solubilized, and finally dropped to $<10$ vol\% near the end of the test (when the soluble TOC was low). The off-gas also contained 0 to 3 vol\% carbon monoxide and $<30 \mathrm{ppm} \mathrm{NO}$, with the balance being oxygen. The increasing concentration of oxygen as the tests progressed indicates decomposition of the peroxide, which becomes more common as the concentration of organic carbon in the slurry drops.

On average, the ion-exchange resin monomers require about $5 \mathrm{~g} \mathrm{H}_{2} \mathrm{O}_{2}$ per gram of monomer for complete oxidation. ${ }^{3}$ The simulant slurry contained $20 \mathrm{~g}$ of ion-exchange resin in $100 \mathrm{~mL}$, and the as-weighed ion-exchange resin contained an average of $56 \mathrm{wt} \%$ moisture. Oxidizing all of the ion-exchange resin would require $56 \mathrm{~g}$ of $\mathrm{H}_{2} \mathrm{O}_{2}$. An additional $28 \mathrm{~g}$ of $\mathrm{H}_{2} \mathrm{O}_{2}$ would be required to regenerate the ferrous iron catalyst if none of the catalyst is regenerated by organic free radicals. Treating $100 \mathrm{~mL}$ of simulant typically required about $111 \mathrm{~g} \mathrm{H}_{2} \mathrm{O}_{2}(180 \mathrm{~mL}$ of $50 \%$ hydrogen peroxide with a density of $1.23 \mathrm{~g} / \mathrm{mL})$; therefore, at least $26 \mathrm{~g} \mathrm{H}_{2} \mathrm{O}_{2}(23 \%$ of the amount added) was decomposed to oxygen, rather than reacting with organic carbon.

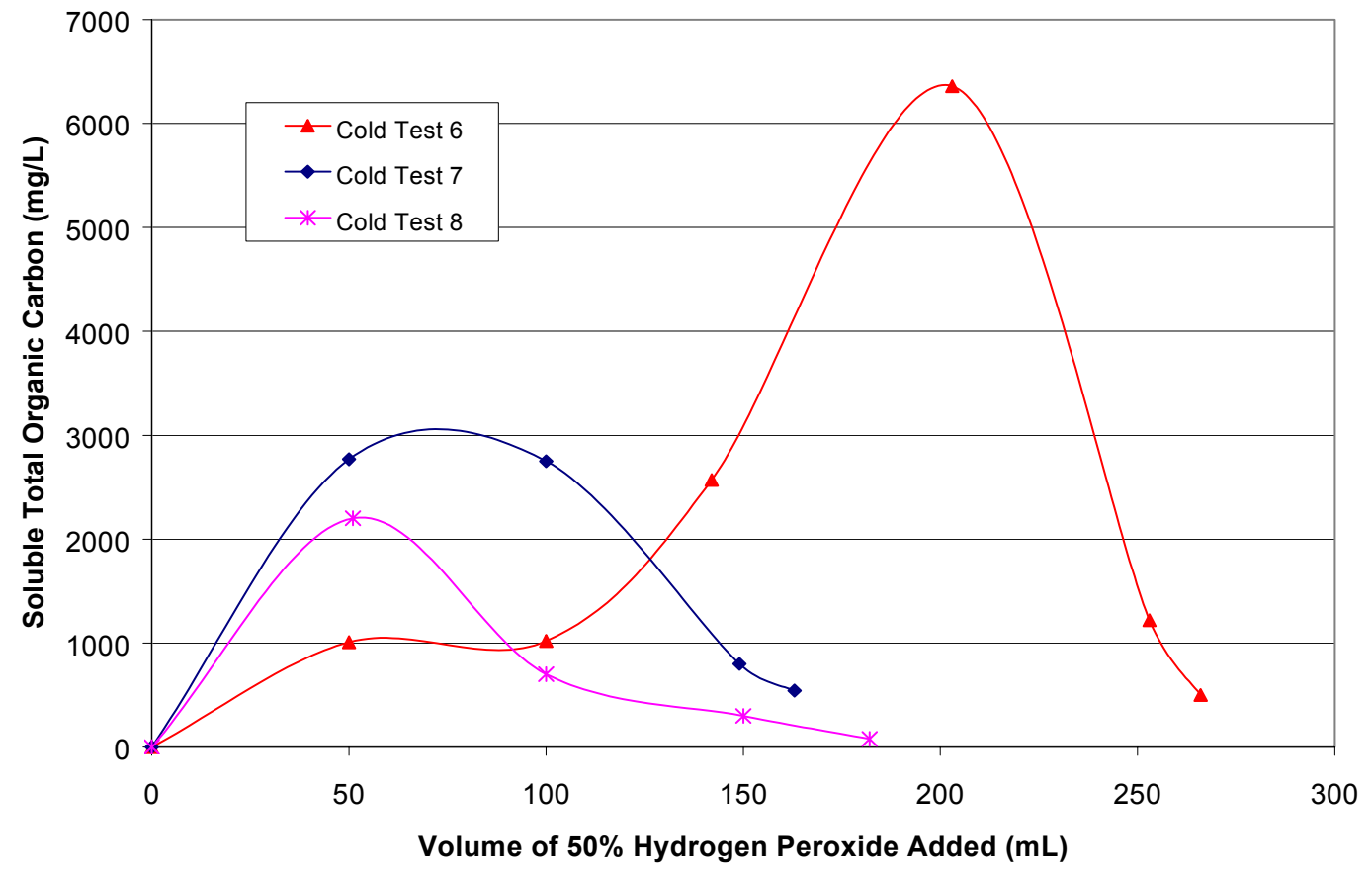

Fig. 4. Concentration of soluble TOC in simulant slurries during treatment.

A simulant of the $\mathrm{T} 2$ tank slurry was used to measure the peroxide reaction rate at various temperatures. At each temperature, the addition rate of $\mathrm{H}_{2} \mathrm{O}_{2}$ was adjusted until a stable peroxide concentration of about $4000 \mathrm{mg} / \mathrm{L}$ was maintained in the slurry. The flow rate of the $\mathrm{H}_{2} \mathrm{O}_{2}$ was measured and the reaction rate was calculated, based on the current volume of the slurry. The reaction rate is very slow until the temperature exceeds $70 \mathrm{EC}$ and then increases almost linearly for temperatures up to $90 \mathrm{EC}$ (see Fig. 5). 


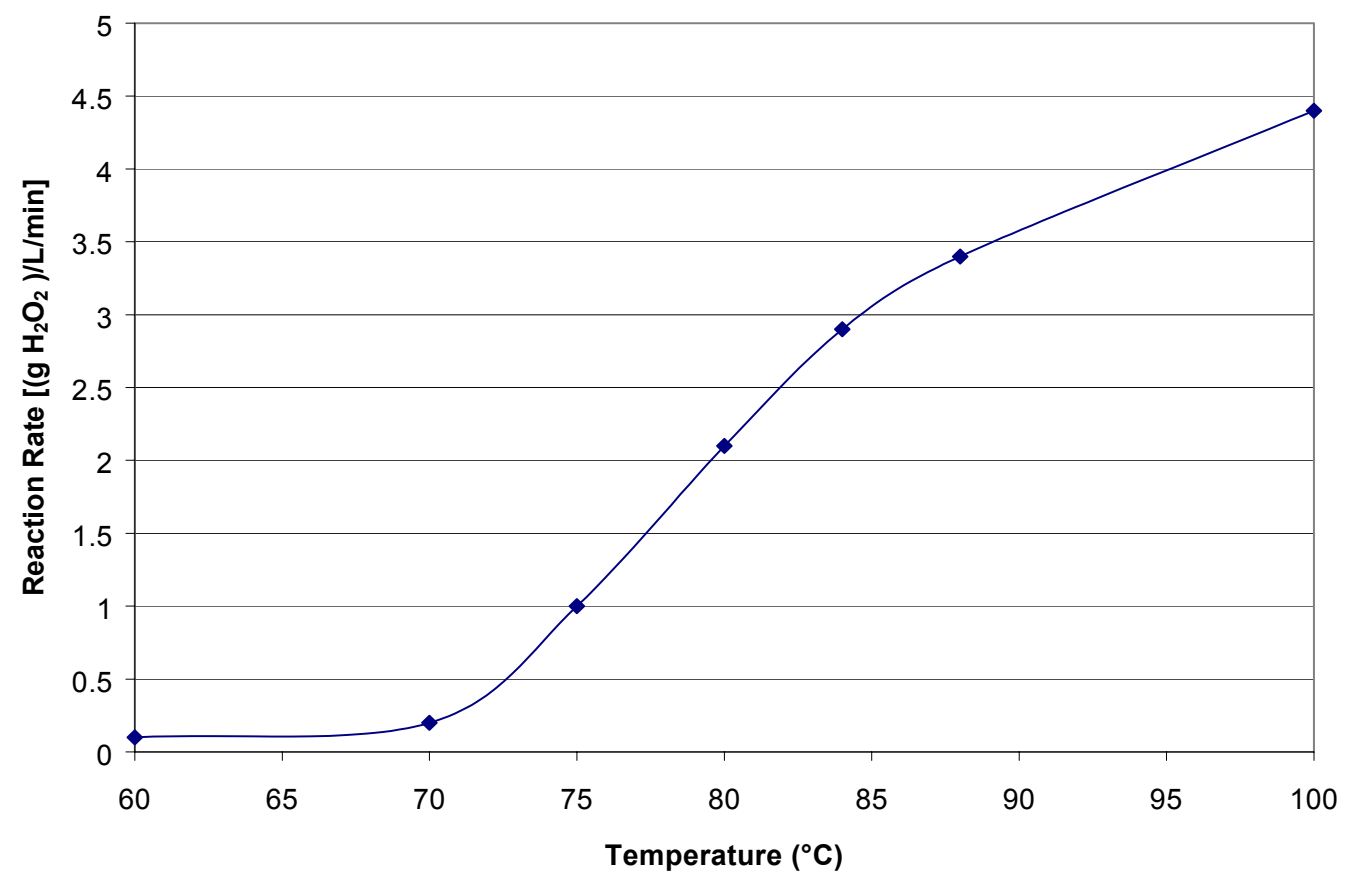

Fig. 5. Effect of temperature on peroxide reaction rate in $\mathrm{T} 1$ and $\mathrm{T} 2$ simulant slurries.

The sample from the T1 tank initially contained about $90 \mathrm{~mL}$ of settled solids and $10 \mathrm{~mL}$ of supernate. A total of $311 \mathrm{~mL}$ of $50 \mathrm{wt} \% \mathrm{H}_{2} \mathrm{O}_{2}$ was used to treat the sample during $12 \mathrm{~h}$ of run time over 4 days. Maintaining the $\mathrm{pH}$ between 3 and 5 required $79 \mathrm{~mL}$ of $1 \mathrm{~N} \mathrm{NaOH}$, and then $9 \mathrm{~mL}$ of $1 \mathrm{~N} \mathrm{HNO}_{3}$. The temperature of the slurry during treatment ranged from 71 to $88 \mathrm{EC}$, with an average of $82 \mathrm{EC}$. A small amount of clear, floating organic liquid was visible after the partially treated sample had sat overnight at room temperature. RMAL personnel tried to identify this floating organic by using gas chromatography, but the liquid would not dissolve in hexane or methylene chloride, which are routinely used as diluents; however, during cleanup of the equipment, the organic dissolved in water. This solubility pattern low solubility in the highsalt, slightly acidic reaction liquid and in hexane or methylene chloride and higher solubility in water suggests that the floating liquid was a weak organic acid. The treated sample contained about $25 \mathrm{~mL}$ of settled solids in a total volume of $150 \mathrm{~mL}$. The slurry contained $1900 \mathrm{ppm}$ of total TOC and the supernate contained $84 \mathrm{mg} / \mathrm{L}$ of soluble TOC. No foam accumulated on the slurry during the treatment.

The sample from the $\mathrm{T} 2$ tank contained about $95 \mathrm{~mL}$ of wet solids and did not have a clear layer of supernate. Treating the sample required $430 \mathrm{~mL}$ of $50 \mathrm{wt} \% \mathrm{H}_{2} \mathrm{O}_{2}$ and almost $16 \mathrm{~h}$ of run time over 3 days. Maintaining the $\mathrm{pH}$ of the slurry required $70 \mathrm{~mL}$ of $1 \mathrm{~N} \mathrm{NaOH}$ and then $31 \mathrm{~mL}$ of $1 \mathrm{~N} \mathrm{HNO}_{3}$. The temperature of the slurry during treatment ranged from 72 to $89 \mathrm{EC}$ and averaged $85 \mathrm{EC}$. The resin in the sample was completely solubilized after only $3 \mathrm{~h}$ of treatment, but a thick layer of clear organic liquid, similar to that observed during the T1 slurry treatment, was visible after the sample had sat overnight. It appears that this layer was a weak organic acid that was initially adsorbed on the ion-exchange resin in the sample and then liberated when the resin was oxidized. As the treatment of the T2 sample continued, the organic layer was slowly destroyed, 
and none was visible in the final treated slurry. The treated slurry contained $30 \mathrm{~mL}$ of settled solids in a total volume of $100 \mathrm{~mL}$. The slurry contained $<1000 \mathrm{ppm}$ total TOC, and the soluble TOC was $556 \mathrm{mg} / \mathrm{L}$. No problem with foaming occurred during the treatment, with, at most, a thin layer of small bubbles present on top of the slurry. Figure 6 shows the trend in soluble TOC concentration for both of the real waste tests as the treatment progressed. It appears that some type of soluble organic was present in the T2 sample that was quite resistant to oxidation by Fenton's reagent, which accounts for the slow decrease in TOC at concentrations below $1000 \mathrm{mg} / \mathrm{L}$ for this sample.

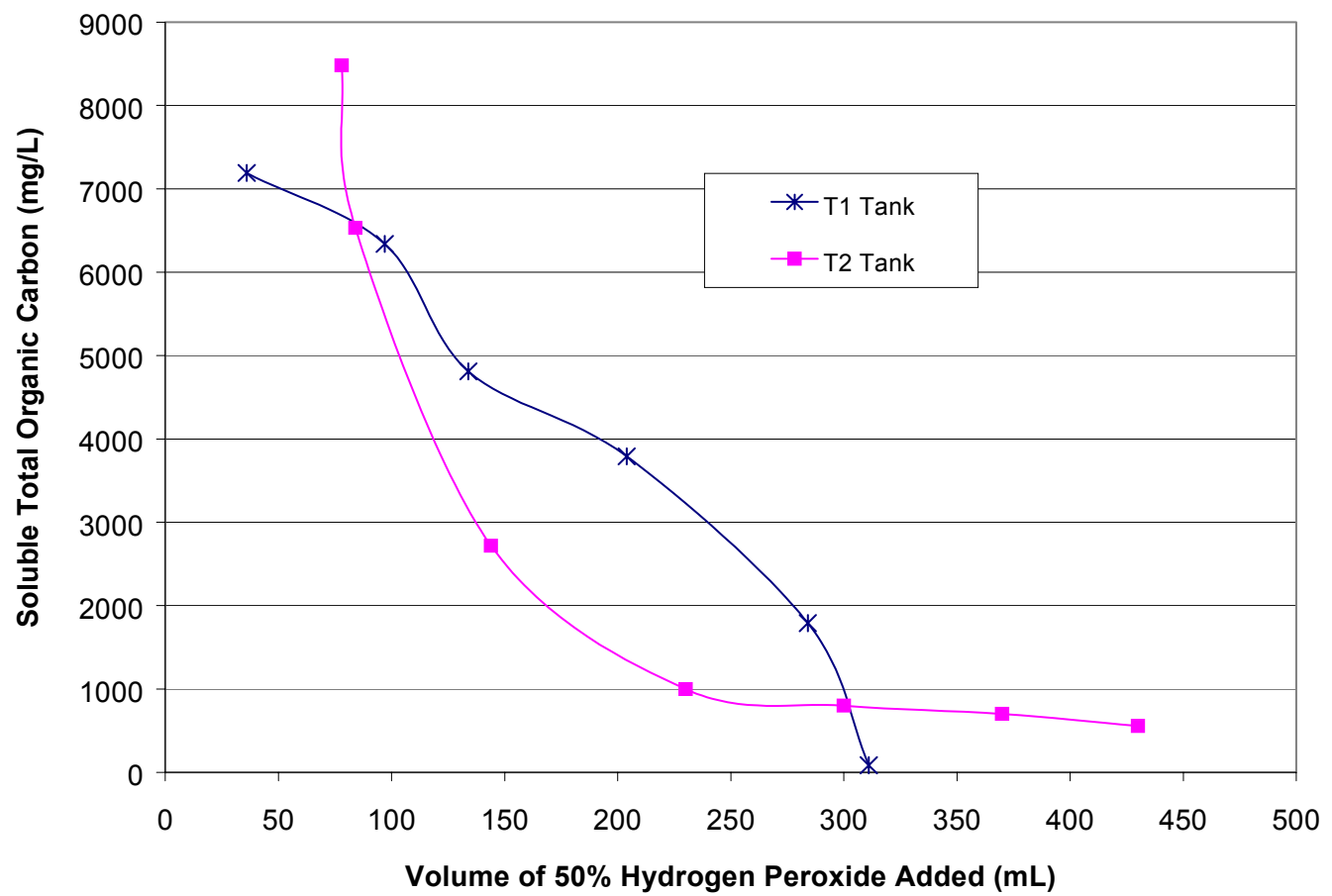

Fig. 6. Concentration of soluble TOC in waste samples during treatment.

\subsection{Pilot-Scale Tests}

The HFIR tank sample initially had a pH of 8.55 , and $15 \mathrm{~mL}$ of $6 \mathrm{NHNO}_{3}$ was used to reduce the $\mathrm{pH}$ to 3.5. Adding $2 \mathrm{~g}$ of $\mathrm{Cu}\left(\mathrm{NO}_{3}\right)_{2}$ further reduced the $\mathrm{pH}$ to 2.3, which was lower than desired; however, hydrogen peroxide addition was started and the reaction proceeded successfully. The sample was treated for $15.5 \mathrm{~h}$ and $2830 \mathrm{~mL}$ of $50 \% \mathrm{H}_{2} \mathrm{O}_{2}$ was used. The hydrogen peroxide addition rate averaged $3.0 \mathrm{~mL} / \mathrm{min}$, which corresponds to a peroxide reaction rate in the slurry of $0.71 \mathrm{~g} \mathrm{H}_{2} \mathrm{O}_{2} / \mathrm{L} / \mathrm{min}$. The hydrogen peroxide concentration in the slurry averaged $500 \mathrm{mg} / \mathrm{L}$, with a maximum value of $2000 \mathrm{mg} / \mathrm{L}$. The slurry temperature was $72 \mathrm{EC}$ when peroxide addition was started, increased to $87 \mathrm{EC}$ after $1 \mathrm{~h}$, and then averaged $89 \mathrm{EC}$ for the remainder of the test. The $\mathrm{pH}$ was controlled with $87 \mathrm{~mL}$ of $2 \mathrm{~N} \mathrm{NaOH}$ and then $58 \mathrm{~mL}$ of $1 N \mathrm{HNO}_{3}$.

Samples were taken every $2 \mathrm{~h}$ and analyzed for total and soluble TOC (see Fig. 7). The first sample taken from the reactor, before any hydrogen peroxide was added, had a total TOC 
concentration of $0.1 \%$, which is much lower than the value of $4.07 \%$ TOC measured for the sample before it was placed in the reactor. Most of the ion-exchange beads were not getting through the sample valve in the recirculation line. Although this valve had worked well for simulant slurries, the beads in the actual waste were stickier. As the reaction proceeded, the beads were reduced in size and finally completely solubilized, so the later samples were more representative of the slurry in the reactor. The TOC results show that $9 \mathrm{~h}$ of treatment and $1650 \mathrm{~mL}$ of $50 \mathrm{wt} \% \mathrm{H}_{2} \mathrm{O}_{2}$ would have been sufficient to completely treat the slurry. Because the samples contained dark-colored particles that were mistakenly believed to be ion-exchange resin, the treatment was continued longer than necessary. The volume of slurry in the reactor, as measured by the level indicator, slowly increased during the test, reaching $3.0 \mathrm{~L}$ at the end of the test. The condensate collection bottle contained $800 \mathrm{~mL}$ of liquid at the end of the test. The TOC concentration in the condensate was $55 \mathrm{mg} / \mathrm{L}$. The treated slurry had a density of $1.01 \mathrm{~g} / \mathrm{mL}$, a suspended solids concentration of $2.92 \mathrm{wt} \%$, and a viscosity of $6.0 \mathrm{cP}$, compared with values of $1.055 \mathrm{~g} / \mathrm{mL}, 7.84 \mathrm{wt} \%$, and $6.73 \mathrm{cP}$, respectively, for the starting slurry. The ENERAC analyzer was not working; consequently, the $\mathrm{O}_{2}, \mathrm{CO}$, and $\mathrm{NO}$ concentrations in the off-gas were not measured.

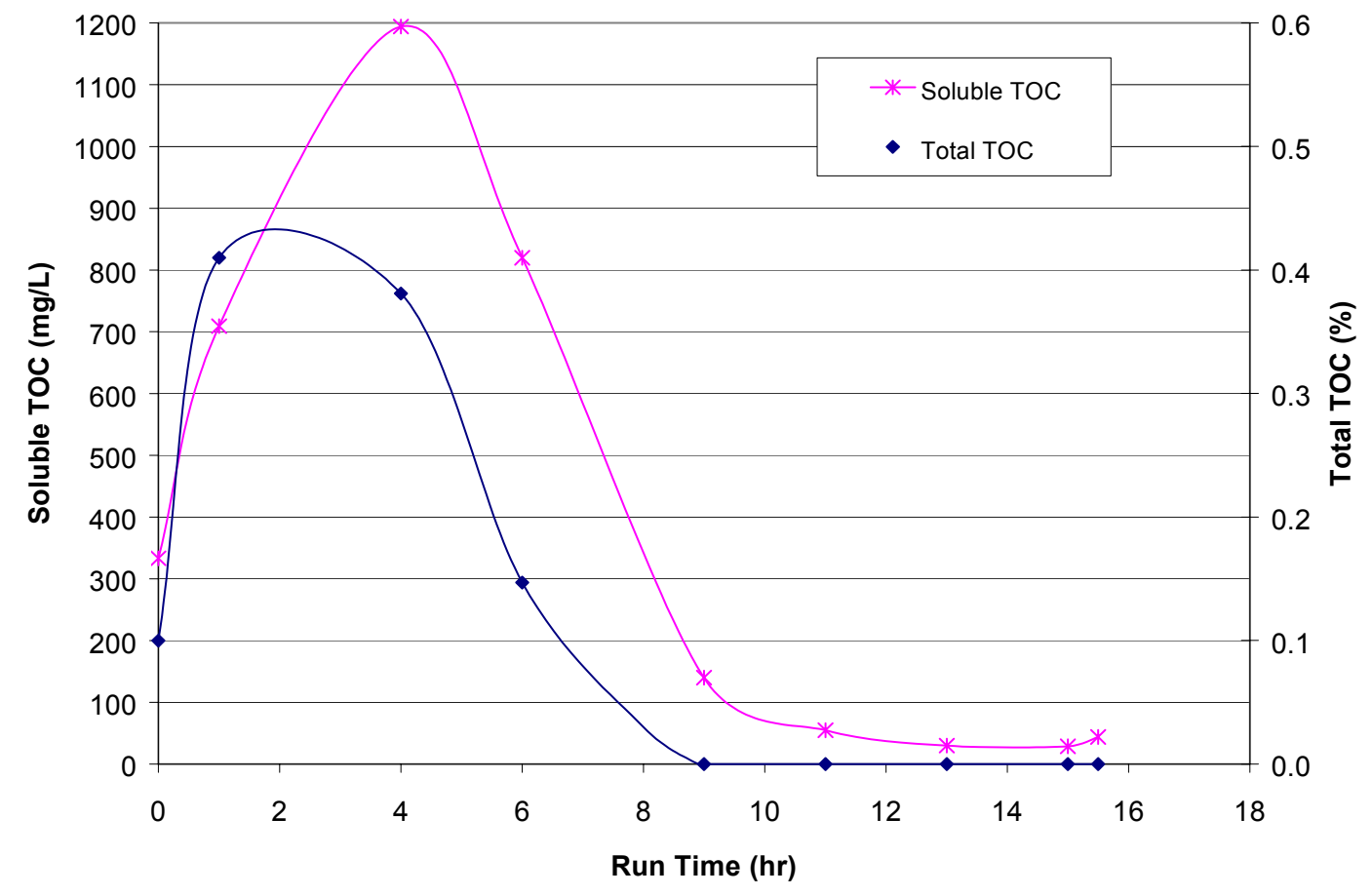

Fig. 7. Total and soluble TOC in HFIR tank slurry during treatment.

The $\mathrm{CO}_{2}$ concentration in the off-gas, which is a mixture of gas generated by the reaction and nitrogen purge gas, was measured using the FTIR analyzer. The results show that most of the $\mathrm{CO}_{2}$ was produced during the first $9 \mathrm{~h}$ of treatment (see Fig. 8). The $\mathrm{CO}_{2}$ concentration in the offgas is a good real-time indicator of the progress of the treatment. Two off-gas samples were analyzed for volatile organics by Ralph Ilgner (ORNL Chemical Sciences Division) using gas chromatography. Trace quantities of several organics were present, with maximum concentrations of $1.1 \mathrm{ppm}$ benzene, $0.7 \mathrm{ppm}$ butanone, and $0.3 \mathrm{ppm}$ decanal. 


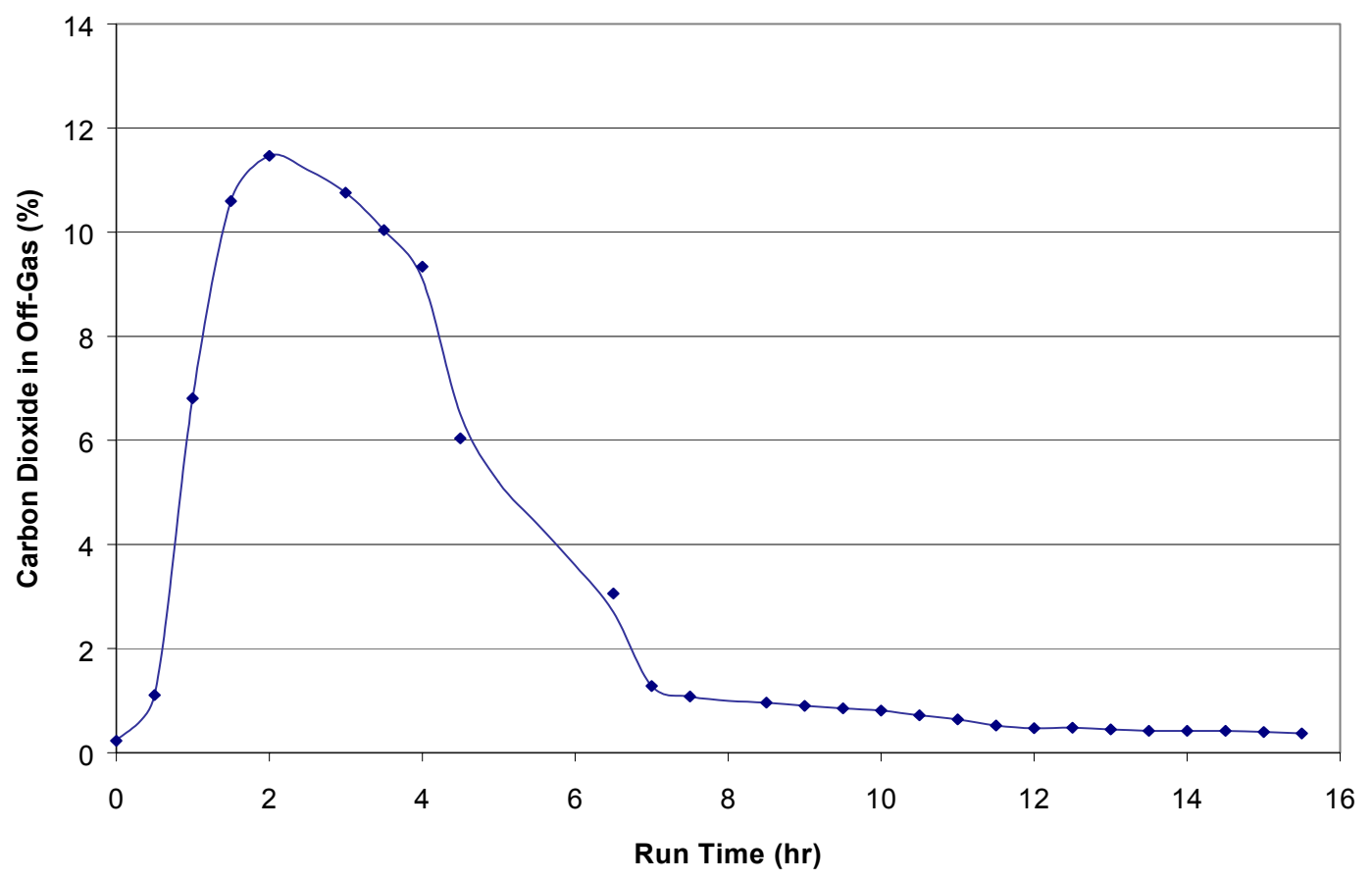

Fig. 8. Carbon dioxide concentration in off-gas from treatment of the HFIR tank sample.

The composite sample from the $\mathrm{T} 1$ and $\mathrm{T} 2$ tanks initially had a $\mathrm{pH}$ of 8.97. Subsequently, $2.0 \mathrm{~g} \mathrm{Cu}\left(\mathrm{NO}_{3}\right)_{2}$ plus $19 \mathrm{~mL}$ of $6 \mathrm{NHNO}_{3}$ were used to reduce the $\mathrm{pH}$ to 3.0. The slurry was treated for $14 \mathrm{~h}$ and $2610 \mathrm{~mL}$ of $50 \mathrm{wt} \% \mathrm{H}_{2} \mathrm{O}_{2}$ was used. The hydrogen peroxide addition rate averaged $3.1 \mathrm{~mL} / \mathrm{min}$, which corresponds to a peroxide reaction rate in the slurry of $0.74 \mathrm{~g} \mathrm{H}_{2} \mathrm{O}_{2} / \mathrm{L} / \mathrm{min}$. The hydrogen peroxide concentration in the slurry was below the detection limit of $100 \mathrm{mg} / \mathrm{L}$ for all of the samples that were tested. The $\mathrm{pH}$ of the slurry was controlled by adding $194 \mathrm{~mL}$ of $2 \mathrm{~N} \mathrm{NaOH}$ during the first $4 \mathrm{~h}$ of treatment, and then no further addition of base or acid was required. The volume of slurry in the reactor increased to $2.4 \mathrm{~L}(20 \%$ volume increase) by the end of the test, and the condensate collection bottle contained $1000 \mathrm{~mL}$ of liquid.

The recirculation line, which contains the $\mathrm{pH}$ and redox probes and the sample valve, plugged several times, but flow could usually be restored by reversing the pump. After $1 \mathrm{~h}$ of operation, the line plugged and could not be unplugged. Treatment continued for another $2 \mathrm{~h}$ while attempts were made to restore flow, but the peroxide addition was then stopped. A section of the recirculation line containing 1/4-in. ball valves was replaced with a new piece containing 3/8-in. valves. Flow was restored through the recirculation line, and the treatment was resumed.

Samples for total and soluble TOC were taken every $2 \mathrm{~h}$, except when the recirculation line was plugged (see Fig. 9). The first sample taken from the reactor, before any hydrogen peroxide was added, had a total TOC concentration of $0.96 \mathrm{wt} \%$, which is much lower than the value of $4.69 \mathrm{wt} \%$ TOC measured for the sample before it was placed in the reactor. As was noted for the HFIR sample, most of the ion-exchange beads were not initially getting through the sample valve in the recirculation line. The TOC results show that the slurry would have met waste acceptance 
requirements after $8 \mathrm{~h}$ of treatment with $1540 \mathrm{~mL}$ of $\mathrm{H}_{2} \mathrm{O}_{2}$, since both soluble and total TOC values were below the levels for the wastes currently stored in the MVSTs.

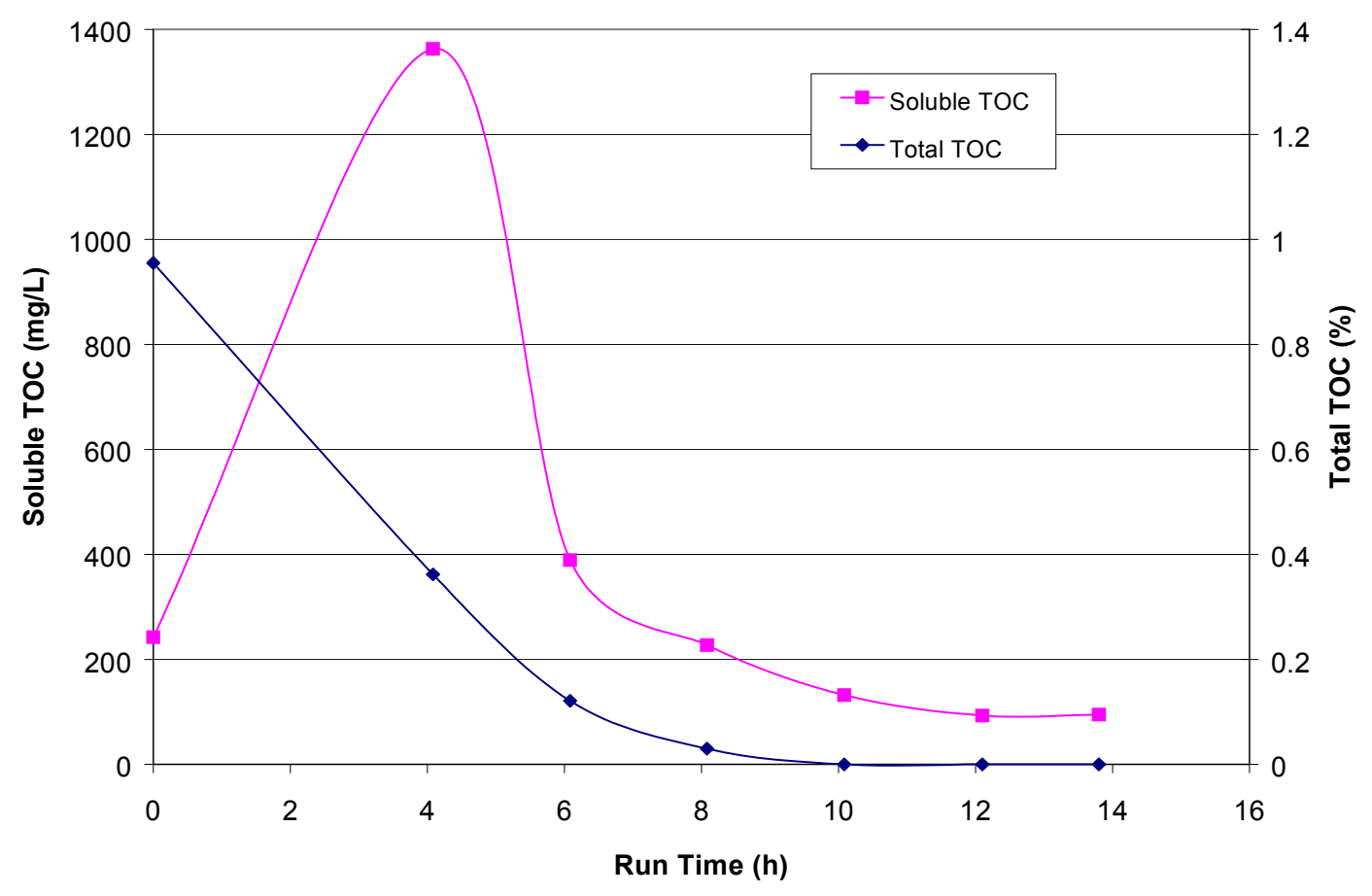

Fig. 9. Total and soluble TOC in T1/T2 composite slurry during treatment.

The floating layer of organic, which was noticed in the laboratory-scale tests using the old samples of T1 and T2 sludge, was not visible in any of the samples from the pilot-scale test. The treated slurry had a density of $1.02 \mathrm{~g} / \mathrm{mL}$ and a viscosity of $5.4 \mathrm{cP}$, compared with values of $1.05 \mathrm{~g} / \mathrm{mL}$ and $5.3 \mathrm{cP}$ for the starting slurry.

The $\mathrm{O}_{2}, \mathrm{CO}$, and $\mathrm{NO}$ concentrations in the off-gas were measured periodically using the ENERAC analyzer, and the $\mathrm{CO}_{2}$ concentration was measured using the FTIR analyzer. The $\mathrm{O}_{2}$ and $\mathrm{CO}_{2}$ concentrations are shown in Fig. 10, and the $\mathrm{CO}$ concentration and off-gas generation rate, which was calculated from the combined $\mathrm{O}_{2}$ and $\mathrm{CO}_{2}$ concentrations in the $1500 \mathrm{~cm}^{3} / \mathrm{min}$ of nitrogen gas added to the reactor, are shown in Fig, 11. Nitric oxide was not detected in any of the gas samples. The off-gas generation rate from the reaction averaged $350 \mathrm{~mL} / \mathrm{min}$, therefore the total off-gas measured by the analyzers contained about $19 \mathrm{vol} \%$ gas that was generated by the reaction and $81 \mathrm{vol} \%$ nitrogen purge gas. Analysis of three samples of off-gas by gas chromatography showed trace quantities of numerous volatile organics, with maximum concentrations of $40 \mathrm{ppm}$ acetone, $21 \mathrm{ppm}$ benzene, and $48 \mathrm{ppm}$ diethylbenzene. The highest concentration of total volatile organics was $122 \mathrm{ppm}$ in the sample taken after $6 \mathrm{~h}$ of treatment, with concentrations of $95 \mathrm{ppm}$ after $4 \mathrm{~h}$ and $55 \mathrm{ppm}$ after $8 \mathrm{~h}$. 


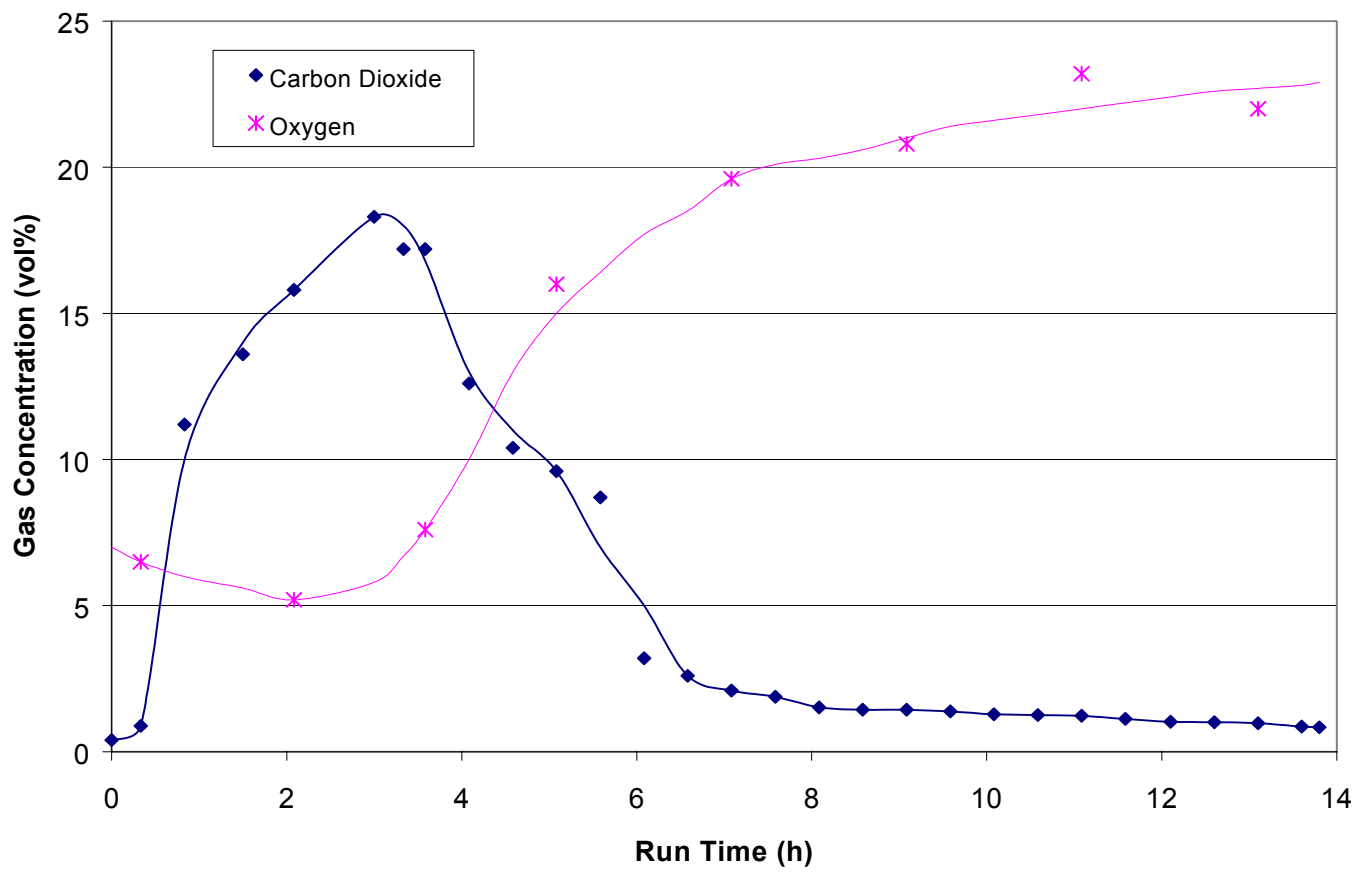

Fig. 10. Carbon dioxide and oxygen concentrations in off-gas during treatment of the composite T1/T2 slurry.

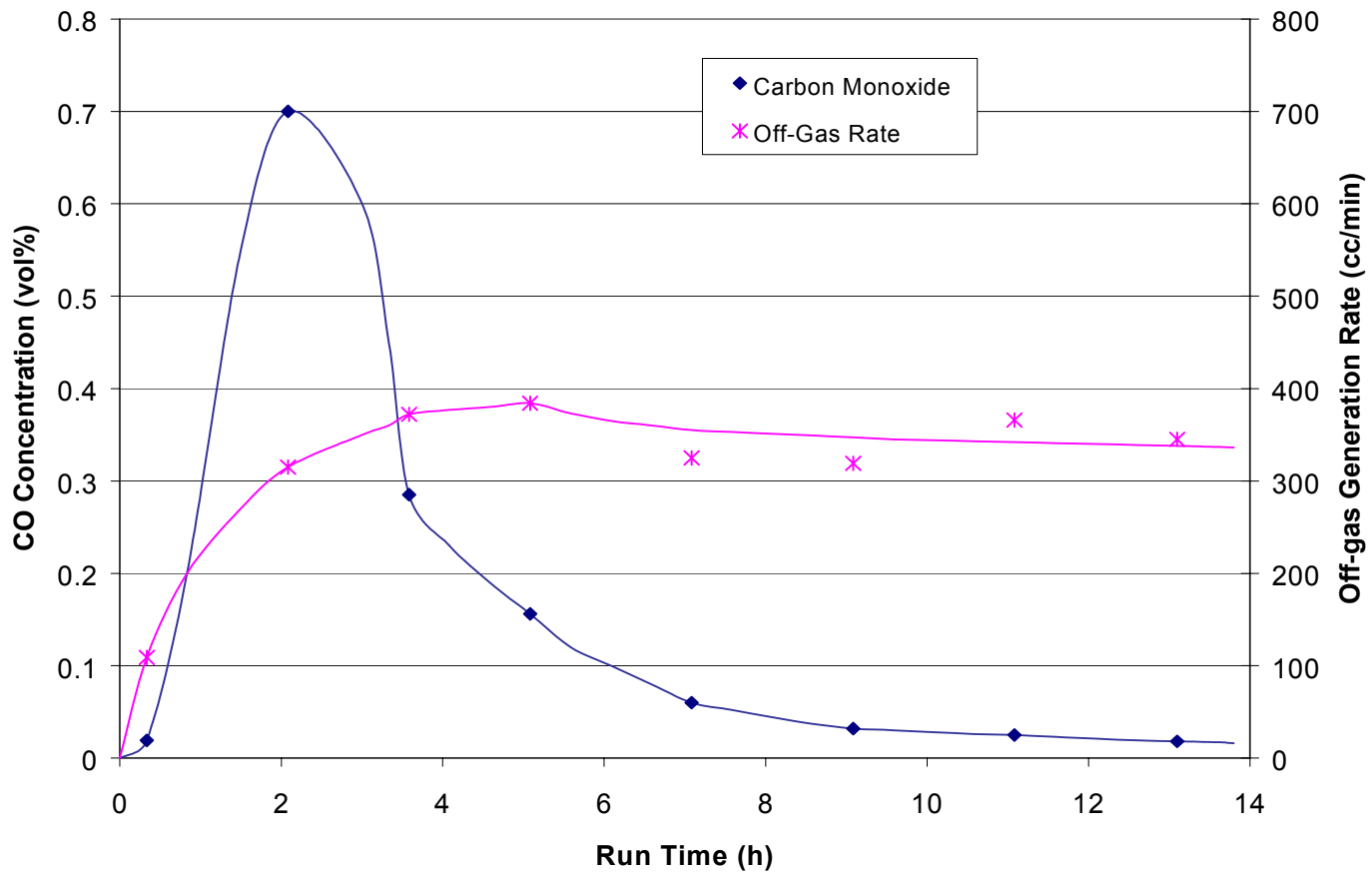

Fig. 11. Carbon monoxide concentration and off-gas generation rate during treatment of the composite T1/T2 slurry. 
The $\mathrm{CO}_{2}$ and $\mathrm{CO}$ concentrations in the off-gas are at a maximum early in the treatment, after part of the ion-exchange resin has been solubilized, when concentrations of both ion-exchange resin and soluble TOC are high. After $8 \mathrm{~h}$ of treatment, when the TOC concentrations in the slurry were low, the $\mathrm{CO}_{2}$ concentration in the off-gas, which is about $81 \mathrm{vol} \%$ nitrogen purge gas, was less than $1.5 \mathrm{vol} \%$.

The composite $\mathrm{T} 1 / \mathrm{T} 2$ slurry contains $31.1 \mathrm{Fg} / \mathrm{g}$ thorium and $4.0 \mathrm{Fg} / \mathrm{g}{ }^{239-240} \mathrm{Pu}$, so the denaturing ratio is only 7.8 , rather than the required 200 . Because the sludge contains high concentrations of depleted uranium, there is no danger of a criticality accident; however, thorium will need to be added to the sludge to meet the new denaturing requirements before the treated sludge can be transferred to the MVSTs.

\section{CONCLUSIONS}

Laboratory- and pilot-scale tests using both simulants and actual waste slurries have demonstrated that Fenton's reagent can be used to destroy the ion-exchange resin in the HFIR, T1, and T2 tanks. The ion-exchange resin is oxidized to carbon dioxide and inorganic salts. The reaction rate is quite slow for temperatures below $70^{\circ} \mathrm{C}$, but the rate increases almost linearly as the temperature of the slurry increases from 70 to $90^{\circ} \mathrm{C}$. Maintaining a $\mathrm{pH}$ between 3 and 5 is optimum, since the reaction rate slows as the $\mathrm{pH}$ drops below 3 and wasteful decomposition of the peroxide increases as the $\mathrm{pH}$ rises above 5 .

A sample from the HFIR tank containing $500 \mathrm{~mL}$ of settled solids with a total volume of $1800 \mathrm{~mL}$ was successfully treated to meet MVST waste acceptance requirements in $9 \mathrm{~h}$ of processing time, using $1650 \mathrm{~mL}$ of $50 \mathrm{wt} \%$ hydrogen peroxide. A composite sample from the $\mathrm{T} 1$ and T2 tanks, which contained $1000 \mathrm{~mL}$ of settled solids in a total volume of $2000 \mathrm{~mL}$ required $8 \mathrm{~h}$ of treatment using $1540 \mathrm{~mL}$ of $50 \mathrm{wt} \%$ peroxide to meet waste acceptance requirements. Hydrogen peroxide reaction rates were 0.71 to $0.74 \mathrm{~g} \mathrm{H}_{2} \mathrm{O}_{2} / \mathrm{L} / \mathrm{min}$, with very low $(<2000 \mathrm{mg} / \mathrm{L})$ concentrations of peroxide in the slurry.

The reaction produces mostly carbon dioxide gas during the early part of the treatment, when organic carbon concentrations in the slurry are high, and then produces increasing amounts of oxygen as the organic carbon concentration drops. Small amounts $(<3 \mathrm{vol} \%)$ of carbon monoxide are also generated. The off-gas from the pilot-scale tests, which was $81 \mathrm{vol} \%$ nitrogen purge gas and $19 \mathrm{vol} \%$ gas generated by the reaction, also showed trace quantities of numerous volatile organics. Maximum concentrations measured were $48 \mathrm{ppm}$ diethylbenzene, $40 \mathrm{ppm}$ acetone, and $21 \mathrm{ppm}$ benzene, with a maximum total volatile organic concentration of $122 \mathrm{ppm}$.

The treated slurries would meet the waste acceptance requirements for the ORNL MVSTs, where other transuranic waste slurries are being consolidated prior to solidification and disposal. Design of the full-scale equipment is in progress, and treatment of the tank contents is planned for 2004. 


\section{REFERENCES}

1. C. K. Bayne, J. R. DeVore and, A. B. Walker, Statistical Description of Liquid Low-Level Waste System Supernatant Liquids at Oak Ridge National Laboratory, ORNL/TM-13351, Oak Ridge National Laboratory, Oak Ridge, Tenn., October 1997.

2. J. M. Keller and J. M. Giaquinto, Characterization of the ORNL MVST Waste Tanks After Transfer of Sludge from BVEST, GAAT, and OHF Tanks, ORNL/TM-2000/323, Oak Ridge National Laboratory, Oak Ridge, Tenn., January 2001.

3. X. Jain, T. Wu and G. Yun, "A Study of Wet Catalytic Oxidation of Radioactive Spent Ion Exchange Resin by Hydrogen Peroxide," Nucl. Safety, 37, 149 (1996).

4. H. J. H. Fenton, "Oxidation of Tartaric Acid in the Presence of Iron," J. Chem. Soc., 65, 899 (1894).

5. F. K. Newheiwat and A. G. Swanson, "Clean Contaminated Sites Using Fenton's Reagent," Chem. Eng. Prog., 96, 61 (2000).

6. Y. W. Kang and K. Hwang, "Effects of Reaction Conditions on the Oxidation Efficiency in the Fenton Process," Water Res., 34, 2786 (2000).

7. S. C. Lee, Dissolution of Ion Exchange Resin by Hydrogen Peroxide, DP-1594, Savannah River Laboratory, Aiken, S.C., 1981.

8. The Treatment of Radioactive Ion-Exchange Resins: Low Temperature Resin Oxidation Process, EPRI-NP-7368-M, Electric Power Research Institute, Palo Alto, Calif., 1991. 


\section{INTERNAL DISTRIBUTION}
1. D. H. Bolling
2. G. F. Boris
3. J. N. Herndon
4. T. D. Hylton
5. D. D. Lee

\author{
6. B. E. Lewis \\ 7. C. P. McGinnis \\ 8. B. B. Spencer \\ 9-12. P. A. Taylor. \\ 13. ORNL Laboratory Records-RC, \\ CRL, OSTI
}

\section{EXTERNAL DISTRIBUTION}

14. L. F. Duquella, U.S. Department of Energy, P.O. Box 2001 MS-EM913, Oak Ridge, TN 37831-8541

15. J. R. Noble-Dial, U.S. Department of Energy, P.O. Box 2001 MS-EM93, Oak Ridge, TN 37831-8620

16. G. L. Riner, U.S. Department of Energy, P.O. Box 2001 MS-EM921, Oak Ridge, TN 37831-8620

17. Edward Danfelt, AEA Technology, 241 Curry Hollow Road, Pittsburgh, PA 15236-4696

18. Martin Williams, AEA Technology, 184 B Rolling Hill Road, Mooresville, NC 28117

19. Steve Taylor, AEA Technology, 184 B Rolling Hill Road, Mooresville, NC 28117 